\title{
Violentos e desordeiros: representações de dois clubes do subúrbio na imprensa carioca (década de 10)
}

CDD. 20.ed. 796.3309

796.5
Nei Jorge SANTOS JUNIOR*

Victor Andrade MELO*
*Universidade Federal do Rio de Janeiro.

\section{Resumo}

Com o intuito de melhor compreender o processo de consolidação do futebol no Rio de Janeiro, esse artigo teve por objetivo discutir as representações de dois clubes do subúrbio, o Bangu e o Andarahy, na imprensa carioca da década de 10. 0 recorte temporal adotado levou em conta que se tratou de um período em que houve um aumento tanto do número de conflitos nos gramados quanto das tentativas de restringir a participação de certos grupos nas iniciativas da Liga Metropolitana de Sports Athleticos. Para alcance do objetivo, analisamos jornais de grande circulação, especialmente o Correio da Manhã e 0 Imparcial. Ao final, concluímos que houve um processo de estigmatização das agremiações investigadas, o que não impediu que participassem ativamente da difusão do velho esporte bretão pela, na época, capital do país.

Palavras-chave: História; Futebol; Esporte; Rio de Janeiro.

\section{Introdução}

Já na primeira década do século XX, a difusão do futebol pelos mais distintos bairros do Rio de Janeiro ${ }^{a}$ desencadeou conflitos no que tange à imagem de distinção social construída e desejada pelos "sportsmen" vinculados àqueles clubes frequentados pelas elites cariocas ${ }^{\mathrm{b}}$. A cada vez maior participação de negros, operários e indivíduos das camadas populares promovia um alargamento simbólico do jogo, que incomodava aos que revestiam a modalidade, pelo menos discursivamente, de um caráter "civilizacional" superior.

Os admiradores do futebol, agrupados em centros esportivos formados nos subúrbios e/ou em seus locais de trabalho, especialmente nas fábricas, começaram a constituir a modalidade como uma expressão de seus desejos sociais específicos. Ao ressignificar a ideia de refinamento e fidalguia construída pelos "sportsmen" das elites, os novos envolvidos aprendiam a fazer desse esporte um de seus principais passatempos, um elemento de identidade social, até mesmo uma alternativa de ascensão social (no caso dos mais habilidosos).

O futebol, assim, paulatinamente transformavase de elemento de diferenciação social em uma prática que, como o carnaval, tendia a subverter as hierarquias ${ }^{1}$. Isso não necessariamente significava a construção de uma oposição de natureza classista.
Tratava-se mais de um processo de apreensão e ressignificação, típico da gestação de uma cultura de massas, que criava possibilidades de ampliação de participação por meio de um mercado de entretenimento que se consolidava. De toda forma, isso em nada era apreciado pelos clubes das elites.

Esses novos personagens, tanto a torcida quanto os jogadores, adotavam certos comportamentos que, no olhar dos setores sociais mais privilegiados economicamente, eram considerados lamentáveis. Por exemplo, não poucas vezes os jornais observaram e enfatizaram que eram marcadas por tumultos as partidas disputadas pelo Bangu Athletic Club e pelo Andarahy Athletic Club, agremiaçôes que se constituíram relacionadas ao ambiente fabril (Fábrica Bangu e Fábrica Cruzeiro, respectivamente), aceitando que indivíduos das camadas populares integrassem suas fileiras ${ }^{2}$.

Considerando que tais manifestações são expressões das tensões observadas no processo de consolidação do futebol no Rio de Janeiro, bem como de uma ordem social marcada pelas tentativas de manutenção de privilégios para determinados grupos, esse artigo tem por objetivo discutir as representaçôes de dois clubes do subúrbio na imprensa carioca da década de $10^{c}$, Bangu e Andarahy, equipes 
que se destacavam por constantemente integrarem a divisão principal do campeonato da Liga Metropolitana de Sports Athleticos ${ }^{\mathrm{d}}$.

O recorte temporal adotado levou em conta que se tratou de um período em que houve um aumento tanto do número de conflitos nos gramados quanto das tentativas de restringir a participação de certos grupos nas iniciativas da Liga Metropolitana. Tratou-se de um momento marcado pela grande difusão do esporte e pela busca de uma melhor estruturação das competições.

Temos clareza de que tema semelhante já foi motivo de investigação em outras oportunidades. Estudos como os de GUEDes ${ }^{3}$, HARDMAN ${ }^{4}$, DeCCA ${ }^{5}$, Antunes $^{6}$, Pereira $^{7}$ e Malaia ${ }^{8}$ abordaram o assunto por diferentes aspectos. A afirmação de ANTUNES ${ }^{6}$

\section{Método}

Para alcance do objetivo, analisamos jornais de grande circulação na cidade do Rio de Janeiro, especialmente (embora não exclusivamente) o Correio da Manhã e O Imparcial. Trabalhamos com todas as ediçóes lançadas entre 1910 e 1922, tendo em conta o recorte temporal de nosso estudo.

O primeiro, fundado em 1901, foi um dos mais importantes órgãos da imprensa brasileira. Apresentava-se como defensor "dos interesses dos pobres e dos oprimidos e divulgador de suas queixas e reclamações"' (p.1625), mas não poucas vezes veiculava mesmo o ponto de vista das elites, ainda que se mantivesse sempre na oposição ${ }^{e}$.

Desde sua fundação, esse jornal destinou um espaço exclusivo para tratar dos esportes. Na seção Correio Sportivo atuaram alguns dos grandes cronistas da cidade, gente que participava ativamente da vida esportiva da capital, como Edmundo Bittencourt, N. Bittencourt (que assinava como "K.K. Réco"), Ary Koerner e Mario Pollo.

\section{Resultados e discussão}

\section{O projeto Silvares}

Na semana final de maio de 1912, a Gazeta de Notícias publicou uma série de matérias sobre os conflitos ocorridos em uma partida realizada entre o São Cristóvão e o Bangu. Aos 20 minutos do bem resume uma impressão geral sobre o envolvimento de populares, notadamente de trabalhadores das fábricas, nos primórdios do futebol brasileiro:

Ao se popularizar, o futebol ganhou novos signi-

ficados simbólicos, ideológicos, socioeconômicos.

Transformou-se em fenômeno social de grande importância, envolvendo uma complexa rede de relaçôes sociais e de interesses, às vezes mais, às vezes menos divergentes ${ }^{6}$ (p.109).

Ainda assim, sugerimos que não é assunto esgotado. Esse estudo não tem a pretensão de contestar ou apresentar olhares absolutamente originais. $\mathrm{O}$ que pretendemos, ao prospectar o tema a partir de novas fontes, é chamar a atenção para certas dimensōes que ainda precisam ser descortinadas ou ao menos aprofundadas.

Seguindo linha semelhante, a abordagem dos problemas políticos e sociais da época, O Imparcial, fundado em 1912, teve uma vida mais curta: sua circulação foi interrompida em 1929. A despeito disso, tratou-se de um dos periódicos mais envolvidos com a divulgação do esporte na cidade do Rio de Janeiro, principalmente do futebol.

O jornal, inclusive, tinha como um dos diretores José Eduardo de Macedo Soares, presidente da Confederação Brasileira de Desportos (CBD) nos anos de 1919 e 1920. Entre os que escreviam na seção Vida Desportiva, o que mais se destacava era Raul Loureiro Filho, conhecido pelo apelido de "Perigoso", por ironizar os principais fatos esportivos ocorridos na cidade ${ }^{10}$.

Para discutir as representaçóes dos clubes, partiremos da discussão de um projeto apresentado por Alberto Silvares, uma tentativa de materializar uma ação de restrição à ampla participação de clubes nos campeonatos cariocas de futebol.

primeiro tempo, discordando da marcação de um gol a favor da equipe da casa, jogadores do clube do subúrbio abandonaram o jogo. Irritados, sócios e torcedores ligados a essa equipe invadiram o campo e agrediram o árbitro Antonio Peres. Com dificuldade, a polícia conseguiu conter a grande 
confusão, com a prisão de alguns membros da agremiação banguense.

Nos dias seguintes, os cronistas esportivos enfaticamente exigiram uma atitude enérgica por parte da Liga Metropolitana de Sports Athleticos - a punição severa dos culpados pelas cenas "degradantes" ocorridas no citado jogo: "se assim proceder, teremos a moralização do Foot-ball association, no caso contrário, não!"11. Depois de apurados os fatos, a entidade dirigente concedeu a vitória ao São Cristovão, a fim de serem evitados fatos futuros semelhantes.

Independentemente da justiça desse julgamento, o fato é que, progressivamente, os clubes da zona suburbana, que aceitavam populares nas suas hostes, transformaram-se em alvos frequentes da grande imprensa que, a todo o momento, os considerava responsáveis pela violência observada nas partidas dos campeonatos promovidos pela Liga Metropolitana.

Vejamos, por exemplo, como o jornalista que assina como João Brigão refere-se ao Bangu:

O Bangu operário, seleccionavel e longínquo, do vil Noelf, velho cansado de lutas e de leituras de longas defesas contra ataques à delicadeza tradicional e inconteste do Leão, se não tivesse sido baptisado pelo antialcoolista Procter $^{g}$ com o doce nome de Bangu Athletico Club, só se poderia cognominar o "Palacio dos Supplicios". Não é allusão ao palácio que Noel projectou para sede da Liga, não! É uma espécie de purgatório, onde os que cobiçam o título de campeones carioca, purgam os pecados, deixando a golpes de canelas, o sangue ruim que lhes corre nas veias. Ali é o verdadeiro laboratório onde se pode apreciar a reacção de Wassermann, tão apregoada. Sangue ruim fica ali, regando aquelle sólo bendito e expurgador das maldades humanas. Sim senhor, seu Noel, num team de onze homens do S. Christovão, trinta attestados de escoriações supercutaneas e esmagamentos de epiderme e seis óbitos e meio. Que team de moças, o do Leão! ${ }^{12}$ Já sobre o Andarahy, apresentado por João Brigão como "democrata e colorido", são mais explícitas as ironias de caráter racial:

Se o projecto-monstro do Joffrissimo Silvares pudesse dar com o Andarahy em casco de rolhas, este club democrata e colorido caberia por herança ao symphatico e alineatico Nico Miranda ${ }^{\mathrm{h}}$. Nem poderia ser de outra forma; o Nico velho é troço naquellas luzidas e encarapinhaticas cabeças ${ }^{12}$.

A crônica faz referência ao "projecto-monstro do Joffrissimo Silvares", um tema que merece nossa atenção por explicitar os incômodos com os clubes mais populares. Alberto Silvares era um dos cronistas da revista Sports, onde assinava suas colunas sob o pseudônimo de Joffre. Foi presidente do Villa Isabel F.C. e um dos maiores defensores da necessidade de melhor selecionar os indivíduos que integravam as equipes de futebol.

Já em 1912, na condição de segundo-secretário da Liga Metropolitana de Sports Athleticos, Alberto Silvares enviou aos filiados uma circular alertando para a necessidade de cumprimento do que preceituava o novo regulamento que estava para entrar em vigor, determinando uma rigorosa fiscalização sobre a profissão dos jogadores que fariam parte das equipes que disputavam o campeonato ${ }^{7}$.

Para alguns, as exigências pareciam absurdas. Um certo J. Sport comentou em $O$ Imparcial:

Com a attenção que merecem, li no Jornal do Brasil de domingo passado, as propostas da commissão de syndicancia e do representante do São Christovão, e o parecer da commissão de informaçōes, a respeito do regulamento daquella commissão para a admissão de jogadores a registro.

De todos esses documentos verifica-se desde logo um intuito muito louvável na apparencia, mas reprovavel, depois de estudo acurado.

Para pertencer ao quadro de jogadores da Liga Metropolitana é mister que o proposto não seja cocheiro, carroceiro, cavoqueiro, barbeiro, soldado, (praça de pret), caixeiro de venda, de hotel, de botequim e uma porção de cousas mais, profissões estas que, no entender dos illustres homens que inventaram esse regulamento, vão desmoralizar e desilustrar os brios da Liga Metropolitana.

Quer dizer: os clubs só podem registrar, os estudantes, officiaes das corporaçôes armadas, empregados públicos e ... o que mais? Não sei. E incrivel, sr. Redactor, que os vinte clubs da Liga possam, manter dois teams com jogadores que pertençam exclusivamente a essas profissōes ${ }^{13}$.

Para os que defendiam a medida, impedir a admissão de jogadores que tivessem profissões consideradas subalternas seria a fórmula ideal para retomar os "tempos ilustres" do futebol. Conforme infere o autor da carta acima: "isto é muito bom para o Fluminense, Botafogo, America, Flamengo, etc., clubs que são, não se pode enganar, compostos de gente da mais fina linhagem. E os outros? Os clubs da $2^{\circ}$ e da $3^{\circ}$ divisões?".

J. Sport apelava para o espírito de justiça. A ser implementado o novo regulamento, estaria inviabilizada a participação das equipes mais populares, que não possuiriam jogadores suficientes que atendessem às "qualidades" exigidas pela Liga. 
A criação de outras divisōes para o campeonato anual já tinha em conta o novo quadro, a presença de um maior número de equipes de procedência distinta. Sendo os times divididos por estratos, pensava-se que o futebol ganharia em número de envolvidos, sem perder o caráter de elite que algumas agremiaçôes tanto desejavam, já que, esperava-se, essas sempre integrariam a divisão principal pela qualidade de seus jogadores.

No entanto, com o advento da Primeira Grande Guerra, o cenário se modificaria com rapidez. $\mathrm{O}$ conflito trouxe problemas para alguns daqueles que sustentavam a ideia de manutenção do futebol "fidalgo", como é o caso do Rio Cricket \& Athletic Association e do Paysandu Cricket Clubi, clubes formados majoritariamente por britânicos. Vários sócios serviram às forças armadas do Reino Unido, o que, em alguns momentos, os deixou praticamente sem jogadores para disputar os campeonatos ${ }^{8}$.

Os estatutos da Liga para o ano de 1914 previam a ascensão do campeão da segunda divisão, com o consequente rebaixamento do último colocado da primeira. Não se esperava que isso pudesse ocorrer com o Paysandu, um dos mais tradicionais da entidade. Atento a tal risco, o representante do Fluminense, Mario Pollo, apresentou, em janeiro de 1915, uma proposta para evitar o trânsito de clubes, sendo enfaticamente apoiado por $O$ Imparcial:

É uma proposta que deve ser recebida com sympathias pelos verdadeiros sportsmen, a que o representante do Fluminense teve occasião de submetter ao conselho da Metropolitana, pedindo para que o Paysandú continuasse a fazer parte da $1^{\circ}$ divisão, e não na posição que presentemente occupa. De facto, o veterano de que fazem parte numerosos membros da honesta e laboriosa colonia ingleza aqui domiciliada, merece a deferencia que lhe pretende conceder o representante do florescente centro sportivo da rua Guanabara. (...). Delle fazem parte excellentes footballers, assas conhecidos dos apreciadores do "association".

Que adeanta aos nossos sportmen a passagem do Paysandú para a $2^{\circ}$ divisão, quando desta passa para a $1^{\circ}$ divisão um outro club cujo valor, podemos affirmar categoricamente, é inferior ao da sociedade ingleza. Não, o Paysandú deve ficar e temos a obrigação de mantel-o par a par com os outros clubs da $1^{\circ}$ divisão. Isto delle ter tirado o ultimo logar pouco importa. Os teams fracos tem tambem os seus dias e a prova disso, já a temos tido por várias occasiōes, facto este que deve concorrer para a estadia do club inglez na $1^{\circ}$ divisão, pois só assim passaremos horas e horas a contar com uma surpreza que nos seja agradavel ou, conforme as coisas, desagradavel.

Os membros do conselho devem levar em consideração a medida proposta pelo sr. Mario Pollo, medida esta que vem mais uma vez provar o quanto de bem intencionado é o distincto sportman. De nossa parte ella tem todo apoio ${ }^{14}$.

A proposta claramente feria um dos princípios esportivos mais anunciados: a meritocracia do resultado. Para Mario Pollo, que também era jornalista do Correio da Manhã, isso era um detalhe. O que não seria admissível era trocar, na primeira divisão, o Paysandu, "veterano club de que fazem parte numerosos membros da honesta e laboriosa colônia inglesa aqui domiciliada" 14 , por outro "categoricamente inferior", nesse caso o Bangu, campeão da segunda divisão em 1914, uma agremiação que, mesmo sendo uma dos fundadoras da Liga, não contava com a simpatia dos cronistas e dirigentes da entidade, por possuir negros e operários em seu quadro.

Em 1915, o Bangu acabou subindo de divisão, e o Paysandu abandonando o campeonato. Nesse ano, curiosamente, seria ameaçado de rebaixamento o Rio Cricket. Composta somente por ingleses, a equipe sofria há tempos com a rotatividade dos jogadores que se deslocavam por várias cidades do país. $O$ redator de $O$ Imparcial noticiava que, desde que começou a guerra, o problema se acentuara. Uma vez mais os periódicos saíram em defesa:

O Payssandu e o Rio Cricket - Juntamos nossas palavras ao coro que se levantava na imprensa a respeito da situação em que se encontram essas duas conceituadas e veteranas sociedades inglezas na Liga Metropolitana.

O Payssandu e o Rio Criket, a quem deve o nosso football os mais relevantes serviços, impossibilitados de participar do campeonato da $1^{\text {a }}$ Divisão e pedem para jogar com os últimos colocados da $1^{a}$ divisão quando quiserem voltar a jogar ${ }^{15}$.

O cronista de $O$ Imparcial, a exemplo que defendera para o Paysandu no ano anterior, julgava ser uma "questão elementar de justiça"16 a permanência do Rio Cricket entre os clubes da elite. Embora essa tenha sido a tônica dos discursos dos jornais, uma vez mais não houve negociação: ascendeu à primeira divisão o Andarahy. O Rio Cricket desistiu de disputar o campeonato, passando muitos de seus jogadores para o Botafogo.

Foi nesse contexto que Alberto Silvares lançou uma nova proposta, mesmo sabendo que suas convicçōes poderiam sacrificar "sympathias e popularidade", principalmente entre aqueles "democratas", que, segundo 
ele, fingiam idolatrar a igualdade. Tratava-se do que afirmava ser uma questão de "puridade". Ninguém entre os dignos sportsmen poderia ser favorável a essa "salada de classes e profissões", mesmo que faltasse "coragem de em público manifestar suas convicções"17.

A posição de Silvares era enfática: "o foottball é um sport que só pode ser praticado por pessoas da mesma educação e cultivo". Sendo intrinsecamente violento, requisitava "entre os muitos predicados para sua pratica regular, antes de mais nada, educação" 17 . Para ele, nas condiçôes colocadas no momento, a modalidade se apresentava como uma negação da realidade social. O autor perguntava por que os sócios dos clubes da elite frequentariam o mesmo espaço que os das agremiações "inferiores":

De modo que nós que freqüentamos uma academia, temos uma posição na sociedade, fazemos barba no Salão Naval, jantamos na Rotisserie, frequentamos as conferências literárias, vamos ao five o clock; mas quando resolvemos a praticar Sport entramos para o Icarahy, club distinto filiado a $3^{\circ}$ divisão da Liga Metropolitana, somos obrigados a jogar com um operário, limador, com um corrieiro, mecânico, chauffeur e profissões outras que absolutamente não estão em relação ao meio onde vivemos. Nesse caso a prática ao sport torna-se um suplício, um sacrifício, mas nunca uma diversão ${ }^{17}$.

Silvares claramente infere que as divisões já não mais atendiam ao desejo de diferenciação social. Ele fazia questão de afirmar que não se opunha à prática do futebol por "esses rapazes dignos no exercício de suas profissões", tampouco propunha que a Liga deixasse de trabalhar para difundir a modalidade pelos mais diversos grupos. Sua objeção era quanto à mistura. Suas críticas se destinavam aos que fingiam aceitar "a ausência de elementares rudimentos de educação" que se verificavam nos clubes populares e a "promiscuidade" da convivência forçada entre indivíduos de distintas classes sociais. A seu ver, isso estaria tirando a elegância e distinção do esporte inglês.

Efetivamente a proposta de Silvares não era excluir as agremiações mais populares da Liga, mas sim separá-las, por "uma questão de princípios", o que significaria, segundo seu olhar, dar um "grande passo para o progresso do futebol carioca"17. Sua reivindicação baseava-se nas restrições que havia em outras práticas esportivas, como no remo, ou em diversões como a dança: "o que nós não queremos é que neste particular o Sport querido pelo povo carioca esteja em condição inferior”. Nesse sentido, defendia a formação de uma "série operária pelos clubs que possuam em seus 'teams' pessoas de determinadas profissōes" ${ }^{17}$.
A proposta foi apresentada com detalhes em 14 de agosto de $1915^{18}$ :

* Série A, composta por várias divisões, todas formadas por sete clubes, cujos componentes não tivessem meios de subsistência nas profissões apontadas na série B. As agremiações que desejassem filiar-se à Liga nesta série pagariam a quantia de $500 \$ 000$ de jóia, além de atender os seguintes requisitos: a) ter secretaria própria; b) ter um campo de acordo com as exigências do regulamento; c) provar que tem renda superior a $300 \$ 000$ mensais.

* Série B, composta por 10 clubes no máximo, cujos membros soubessem ler e escrever, além de apresentarem bom comportamento e possuíssem meios de subsistência por pertencer às seguintes profissōes: a) operários ou oficiais; b) empregados de chapa da Light and Power, estafetas dos telégrafos, correios, serventes, condutores, motorneiros e chofer; c) caixeiros de botequins, e outras em idênticas condições, inclusive todos os que recebem gorjetas; d) lustradores, engraxates, pedreiros, tipógrafos, sapateiros e carpinteiros; e) guarda civil.

* Serie C, equipes de praças e inferiores de qualquer corporação armada, que soubessem ler e escrever e que tivessem um comportamento reconhecidamente exemplar. O campeonato desta série seria disputado por times representativos dos corpos, regimentos ou batalhões, não sendo permitido mais de dois times de cada corporação.

A princípio, o projeto foi aclamado por alguns órgãos de imprensa, que em boa parte parecia concordar com as propostas de separação. $\mathrm{Na}$ visão de alguns, isso seria mesmo uma contribuição para os membros dos clubes mais populares. Por exemplo, para o cronista de $O$ Imparcial seriam beneficiados não só os "footballers de maior educação", como também "os menos educados, que se sentiriam obrigados, para não passarem como tais, a seguir o exemplo daqueles" ${ }^{\prime \prime}$.

O projeto de Alberto Silvares, todavia, logo seria muito criticado. Uma carta publicada na Gazeta de Notícias, assinada por um certo "acatado Sportman Sr. Firmino de Carvalho”, atacava não só as propostas como o apoio dado por O Imparcial, cobrando mais imparcialidade, já que, lembrava, o proponente era representante do Villa Isabel F.C. ${ }^{20}$.

$O$ redator de $O$ Imparcial, em resposta, declara que sua relação com Silvares era apenas de cortesia: "nenhuma outra ligação de qualquer natureza nos obriga a dizer 'amen' a tudo quanto possa gerar o seu cérebro fecundíssimo" ${ }^{21}$. Mais ainda, se posiciona: "a seleção existe em todos os ramos da atividade 
social", até mesmo "os frequentadores dos sambas dos cordōes carnavalescos não são, positivamente, os mesmos dos salóes dos diários", inclusive nos bondes "encontramos a primeira e a segunda classe e, para não irmos muito longe, nos próprios campos de football os assistentes são selecionados, ficando uns nas arquibancadas e outros nas gerais".

Assim sendo, o jornalista indaga: "Por que motivo não havemos de fazer a seleção entre os que praticam um "Sport", cuja natureza violenta requer da parte destes o máximo de educação para o refreamento dos ímpetos de reacção?"21. Para ele, "se as diversas classes sociais têm suas associaçōes beneficentes, recreativas e de outras espécies perfeitamente separadas que mal pode haver quando se procura fazer o mesmo no terreno do sport?". Vejamos que se repetiam argumentos semelhantes aos de Silvares à busca de legitimar o processo de separação. $\mathrm{O}$ apoio era explícito.

Alguns dias depois, outra carta abordava o assunto, desta vez publicada no Correio da Manhä, assinada pelo marinheiro L.M., dirigida "ao sr. redactor sportivo do Imparcial e ao sr. Alberto Silvares, representante do Villa Isabel Football Club na Liga Metropolitana"22.

O autor lembra que, a despeito de sua profissão, assistia aos "matches" nas arquibancadas, "onde os moços bonitos que freqüentam o Club dos Diários e fazem o 'footing' costumam mimosear-se entre si com bengaladas e dirigirem impropérios aos 'referees' e aos jogadores”, como vira em 1910, numa partida entre o Botafogo F. C. e o America F. C., "clubes estes filiados à Metropolitana, compostos não por praças de pret $\mathrm{e}$ nem por engraxates", mas sim por moços da "elite".

Segundo L.M., no decorrer desse jogo "houve bofetadas, sendo necessário o comparecimento da polícia, isto é, de praças de pret, para acalmar os ânimos dos contendores, que eram os tais moços bonitos e de educação". Cita ainda conflitos semelhantes que houve em uma partida realizada entre o America F.C. e o Fluminense F.C. Para o autor da carta, tratava-se claramente de preconceito achar que o monopólio da violência pertencia aos populares.

No dia seguinte, uma resposta indignada ao marinheiro foi publicada em O Imparcial:

Sr. redactor de sport do "Correio da Manhâ" e

"Gazeta de Notícias", uma carta assignada por "um marinheiro", diz haver desgostos na nossa classe por causa de um projecto da selecção. Peço desmentir semelhante affirmação, pois tal lei, não nos atinge nem nos preocupa, pois não pretendemos tomar parte em campeonatos da Liga Metropolitana.

Temos a Liga da Marinha que organizou campeonatos de football e outros sports a nós destinados.
Nós, entretanto, não autorizamos a ninguém a falar em nosso nome. - "Um marinheiro de verdade"23.

A posição é no mínimo suspeita. A Liga de Sports da Marinha acabara de ser criada e muitos dos seus membros ainda faziam parte da Liga Metropolitana, principalmente dos clubes oriundos dos subúrbios da cidade. Além disso, a carta estava acompanhada de outra redigida pelo próprio Alberto Silvares, na qual o mesmo se defendia:

$\mathrm{O}$ intuito mesquinho da pessoa que não teve coragem de assignar o próprio nome e foi covardemente, sob a capa de "um marinheiro" escrever aquella carta aos jornais, só teve em vista dar vazão aos seus sentimentos de hostilidade contra os clubs Botafogo, America e Fluminense, e indispor o autor do projecto da selecção com os marinheiros nacionaes, papel esse pouco digno, mas que absolutamente não me dará recuar. Os factos citados na sua carta, referentes a incidentes em campo; aliás, bem raros, pois só são citados dois, verificados entre gente limpa é a causa mais humana. Uma ingenua pergunta: "A França, a Allemanha, a Inglaterra, etc... empenhadas na mais horrorosa das guerras não serão nações civilizadas?"23.

$\mathrm{Na}$ mesma semana, mais duas cartas sobre o tema foram publicadas no Correio da Manhã. A primeira, com papel timbrado da Fortaleza de Villegagnon, assinada por B.M., reforça a ideia de que os marinheiros não desejavam fazer parte da Liga Metropolitana, pois desfrutavam da Liga de Sports da Marinha, na qual "privam com pessoas de alto conceito social" 24 .

A segunda, assinada por José Azevedo de Sobral, ao contrário, taxava o projeto de "uma peça pretensiosa, ilógica e iníqua" ${ }^{24}$. Lembrava que os clubes filiados à Liga conquistaram esse lugar por meio de "provas desportivas e sacrifício pecuniário não pequeno". De acordo com os estatutos, "eles foram julgados dignos de tal associação, gozando de igualdade de direitos e capacidade social".

Integrar a Liga tornou-se, portanto, "um direito adquirido de cujo gozo não seria para temer, legalmente, a turbação por um projeto tumultuário e irrito, ulterior a lei que conferiu esse direito" 24 . Segundo seu olhar, nenhum clube, sem que tenham perdido a capacidade civil, poderia ser excluído da Metropolitana ou ver diminuídos os seus direitos.

Sobral, logo, clamava por respeito à meritocracia de resultados, independente de "laços de sangue" ou "nomes de família", um debate, aliás, muito em voga em um país que recentemente aderira à República e abolira a escravidão. 
Outras denúncias abalariam a proposta de Silvares. Publicada em 22 de fevereiro de 1916, no Correio da Manhã, a carta assinada por um primeirotenente da marinha, E. M. de Sousa, explicitaria uma suspeita já antes sugerida: o intuito real era trazer para a primeira divisão o Villa Isabel F.C.

De fato, se aprovado, o projeto excluiria o Bangu e o Andarahy, sempre candidatos à primeira divisão, abrindo caminho para o Villa Isabel, já que o Carioca F.C., que comumente tinha boa performance na segunda divisão, também jogava com operários.

Rodeado de contestações, o projeto de Silvares não foi à frente, mas teve vários desdobramentos. De um lado, alavancaram-se discussões que favoreceram politicamente os clubes oriundos das camadas populares da cidade do Rio de Janeiro ${ }^{7}$. De outro lado, uma nova lei do amadorismo geraria muitas polêmicas, um debate que só resolver-se-ia nos anos 30.

$\mathrm{O}$ que não cessou de forma alguma foi o processo de estigmatização.

\section{Fortalecem-se os estigmas}

25 de novembro de 1919. Os principais jornais cariocas anunciaram, com indignação, a interrupção do "match" entre o Andarahy e o Villa Isabel, realizado no dia anterior. Nos momentos finais do período inicial do jogo, após um choque entre um atleta de cada time, a torcida do primeiro invadiu o gramado. Depois de muitas pauladas, tiros e navalhadas, a polícia pediu reforços e conseguiu dar fim ao tumulto, com a prisão de alguns envolvidos.

Dois dias após o incidente, O Imparcial publicou uma carta do árbitro da partida, Max Eckstein, em que lastimava os atos de violência cometidos por alguns torcedores: As "torcidas", covardemente, se dirigiram para a porta de minha residencia, sabendo-me no campo do Jardim Zoologico e minha senhora sozinha, sem que nada soubesse, foi ameaçada por mais de 40 indivíduos, alguns mostrando punhais e revólveres, que, além disso, deram assustadoras noticias a meu respeito, entre ellas, que eu tinha sido navalhado e aguardava em campo os socorros da assistência. Se não fossem as garantias prestadas pela policia local, a pedido de minha esposa, que para lá mandou uma "viuva alegre" e duas praças de cavallaria, não sei de que seriam capazes os audazes indivíduos, que, por infelicidade, são "torcidas" do Andarahy ${ }^{25}$.

uma "viuva alegre" e duas praças de cavallaria, não sei de que seriam capazes os audazes indivíduos, que, por infelicidade, são "torcidas" do Andarahy.
Para o árbitro, não havia justificativa para tal violência, inclusive porque atuara com lisura e eficiência: "a explosão da assistência, só pode ser attribuida ao fanatismo cego de certos indivíduos, que não conhecem as regras de football e muito menos de educação".

No mesmo dia, o vice-presidente do Andarahy, Antonio de Miranda, publicou uma nota desmentindo essas informações.

A directoria do Andarahy A.C., a bem da verdade, vê-se na contingência de desmentir o chronista do matutino do Largo da Carioca, quando se referiu, em sua edição de hontem, ao match e conflicto havido no campo do Jardim Zoologico.

Assim contesta ella, por não ser verdade:

Que tivesse sido chamada para depor em qualquer delegacia de polícia; que tivesse havido navalhadas no campo de football; que tivesse sido o autor do conflicto seu associado Gilabert, tendo em vista que o mesmo chronista attribue na mesma descripção do seu jornal a autoria da aggressão e causa do referido conflicto á outra pessoa que se julgara chargeada por ser um adversario ${ }^{26}$.

Uma vez mais vemos o conflito simbólico que se estendeu por anos no cenário do futebol carioca. Se por um lado esses acontecimentos reforçavam e explicitavam o intenso relacionamento existente entre os torcedores e as agremiações do subúrbio, por outro lado fortaleciam um processo de estigmatização claramente em curso na grande imprensa carioca.

Nas palavras de Mario Pollo, cronista do Correio da Manhã, essas agremiaçóes seriam responsáveis por afastar dos estádios as "boas famílias cariocas", que não se conformariam em passar por uma situação "absolutamente incômoda e desagradável” ${ }^{27}$. Na maior parte das vezes, era assim que os clubes do subúrbio eram retratados nos periódicos cariocas: se eram inegáveis os conflitos, também o eram os preconceitos.

Vejamos, por exemplo, a narração do jogo entre o Bangu e o Fluminense, realizado em junho de 1917. São explícitos os estereótipos usados pelo cronista, que não enxergava, nos sócios e torcedores do time do subúrbio, o refinamento desejado para a sociedade carioca: No longínquo campo do Bangu A.C., realizou-se, ontem, o embate entre os teams desse club e os do sympathico Fluminense F.C.

O querido club da rua Guanabara conseguiu, ontem, brilhantemente, coisa que, o anno passado, não succedia com os teams que demandavam aquelle campo, derrotar o valoroso Bangú.[...] Como referee actuou o Sr. A. Almeida cuja actuação desgostou os partidários do club local, os quais tentaram aggredil-o. 
O jogo desenvolvido pelo team local foi violento como sempre, tendo sahido machucados os players Lais e Emmanuel do Fluminense.

A liga precisa, quanto antes, tomar séria providencia para que não tenhamos muito em breve de ver aleijados em nossos campos, pelos jogadores "vallentes", aquelles que procuram no football um divertimento. Das vítimas de hontem em campo, Emmanuel foi quem mais soffreu, tendo se recolhido á residência de seus progenitores, onde está em tratamento, com um dos braços desarticulado.

Ao deixar a estação de Bangú o trem especial do Fluminense no qual vinham muitas famílias, foi apedrejado por um grupo de desordeiros.

Felizmente a não serem as vidraças quebradas não se verificou nenhum desastre pessoal. Coisas do Football ${ }^{28}$.

Observam-se nesta citação dois pontos importantes que merecem ser explorados. O primeiro é a elogiosa referência ao "sympathico Fluminense F.C.", "o querido club da Rua Guanabara”, que teria sido vítima de todos os descalabros. A admiração e reverência do cronista d' $O$ Impacial eram observadas também em outros órgãos da grande imprensa. Para essa agremiação constantemente eram dedicados elogios e sinais de reconhecimento.

A equipe da Zona Sul, que sempre teve entre seus sócios e frequentadores representantes das famílias economicamente mais prósperas da cidade, simbolizava os "tempos áureos" do jogo, algo que, supostamente, não era mais encontrado dada a presença de jogadores oriundos da periferia.

O segundo ponto, portanto, se articula a esse anterior: a sugestão de que eram comuns condutas violentas nos jogos do Bangu, especialmente quando se realizavam em seu "longínquo" campo. Ao contrário do Fluminense, para o clube do subúrbio poucos elogios havia. Seus jogadores, torcedores e sócios eram somente reconhecidos por suas supostas posturas inadequadas.

Três dias após o incidente, no mesmo periódico, publica-se uma carta do presidente do Bangu, Noel de Carvalho, na qual identifica e denuncia o estigma. Para ele, sempre que a imprensa carioca se refere a seu clube, do qual diz sentir muito orgulho de pertencer, o trata de um modo injusto e agressivo, no qual "transparece não o desejo de pugnar pelo engrandecimento e moralidade do Sport, mas tão somente a intenção de amesquinhar esse modesto núcleo de cultura physi$\mathrm{ca}{ }^{29}$. O dirigente lamenta que os responsáveis pelas seçôes esportivas dos jornais estivessem obcecados pelos: preconceitos sociais, que os levam a analisar por prismas diversos factos, já quando estes se apresentam no meio do elemento operário, já quando estes surgem no coração da "elite", no meio daqueles mais favorecidos pela fortuna.

Sem negá-los, Noel ameniza os fatos ocorridos: “a diretoria do clube, com o prestígio de que goza e de que se ufana, conteve prontamente esse movimento, e irá corrigir aquelles que promoveram". Segundo ele, os fatos receberam a reprovação "unânime dos sócios do Bangú e da população local”. O presidente, aliás, faz questão de lembrar que o bairro não é habitado "por selvagens ou botocudos"; trata-se sim de uma região "laboriosa e de população pacata".

Por fim, Noel lança uma provocação: não se pode confundir a agremiação com a ação de "alguns elementos exaltados, desses que existem em todos os clubs, desses de que o Bangú A. Club não tem privilégio". Lembremos a já discutida carta do marinheiro que criticava o projeto de Alberto Silvares: também nos clubes da elite havia turbas e violência.

De fato, a estigmatização fica ainda mais clara quando observamos como os conflitos que ocorriam nos clubes das elites eram tratados pela imprensa: não eram noticiados com o mesmo grau de dramaticidade, por vezes sendo até elogiados, considerados com uma expressão de amor à equipe ${ }^{j}$. Mais ainda, não poucas vezes, mesmo quando os incidentes ocorriam nos campos das equipes mais "nobres", com a total participação dos seus sócios e adeptos, a responsabilidade era atribuída aos torcedores "impertinentes e mal educados" do subúrbio ${ }^{7} \mathrm{Na}$ visão de cronistas não havia dúvidas: eles possuíam o monopólio da falta de educação esportiva.

Vejamos um curioso caso. No campeonato de 1922, os conflitos observados em um jogo entre o America e o Flamengo foram assim comentados:

Uma vez que nos referimos às brigas entre os assis-

tentes, provocadores de arruaças que, comumente se verificavam, hoje, dá-se justamente o contrário. Os moleques, os arruaceiros, os que provocam brigas e barulhos que exigem a acção immediata da policia, ficam justamente entre o publico que se aglomera nas archibancadas, ao passo que nas geraes reina uma ordem nunca vista.

Somos justos: a gente melhor fica hoje nas geraes... Se só é nas archibancadas que se briga, que se agride, que se offende os juízes... ${ }^{30}$.

Essas declarações, excepcionalmente contrárias aos que frequentavam as arquibancadas, não passaram incólumes: na edição do dia seguinte uma reparação foi publicada. Tentando corrigir o que afirmara, o cronista declara que, "de tal modo como ficou dito", pareceu que os conflitos aconteciam "somente entre 
os que estão nas archibancadas do sympathico club da Rua Campos Salles"31, o que não era o caso.

Com a justificativa de não ter citado qualquer agremiação, alegou que, na verdade, quis dizer que entre as brigas "salientam-se as que se originam nas archibancadas, ao passo que os assistentes das geraes tem tido um comportamento não confirmados do conceito máo em que eram tidos”.

Ao fim, o jornalista deixa claro: em momento algum teve o intuito de ofender os clubes envolvidos, ambos, aliás, ligados às elites cariocas. Havia uma clara preocupação de não macular a imagem das agremiações envolvidas.

Um dos que, na própria imprensa, observou esse tratamento diferenciado foi Lima Barreto. Em artigo publicado em Careta, de 1 de janeiro de 1921, o literato pôs em discussão uma notícia veiculada pelo jornal A Noite, em 13 de dezembro de 1920, na qual expôs um conflito ocorrido em um jogo realizado entre as equipes do Mangueira e do Fluminense, narrado como se fora responsabilidade da primeira equipe.

Barreto também chama a atenção para o fato de que não era somente nos campos dos clubes de "terceira ordem" que os conflitos ocorriam; nos estádios das agremiações das elites "também se tem timbrado nesses desrespeitos à assistência, não atendendo sequer á presença de senhoras, que são atropeladas nas correrias e até agredidas, devido á confusão"32. Para ele, aliás, "trancos e pontapés" eram típicos da modalidade, logo "clubs aristocratas e puros" não seriam distintos dos "clubezinhos do subúrbio": “O football é uma e mesma coisa em toda parte!"k.

$\mathrm{Na}$ verdade, o que fica claro é que havia um preconceito de classe, não poucas vezes se estabelecendo uma relação linear dos comportamentos dos criticados com sua condiçãao social. Esse tipo de postura não era uma novidade no Brasil, sendo muito próxima àquelas observadas ao se noticiar a "loucura mística" de Antonio Conselheiro, a ignorância e imundície dos moradores dos cortiços cariocas e a subversão e desordem das organizaçôes proletárias ${ }^{33}$. Vejamos um exemplo explícito no âmbito do futebol:

Ainda hontem no campo do Bangu A.C., por occasião do encontro dos teams locaes com os do S. Christovão, registraram-se factos que são tão indignos, que mais mereciam ser lamentados numa secção policial.

Faltando 22 minutos para terminar o encontro Patrich perdendo a pelota para Hugo aggride este jogador no que é repellido.

Estabeleceu-se o tumulto, que teve como conseqüência a invasão do campo, novas aggressōes, pauladas, revolvers e navalhas em scena e.. suspensão do jogo!
Não sabemos ainda quaes os culpados de tamanha falta de educação: se os desordeiros da Favella ou se os agressores do Morro Pinto.

Francamente, srs. Sportmen. Isto nunca foi football! Acabemos com estas scenas lamentáveis, antes que a policia prepare um logar seguro para serem trancafiados os desordeiros que se querem impingir como sportmen! $!^{34}$

No seu estudo sobre o cotidiano das camadas populares, CHALHOUB ${ }^{35}$ ajuda-nos a entender porque os conflitos eram tradicionalmente abordados como se fossem de exclusiva responsabilidade dos "desordeiros da Favella" ou dos "agressores do Morro Pinto", como vimos na notícia. Para os teóricos da patologia social, a pobreza produziria a ausência de normas ou a falta de padrões de comportamento. A culpa é sempre dos pobres.

Selvagens, bárbaros e inferiores foram denominações constantemente utilizadas por integrantes das elites brasileiras em referência aos escravos, libertos, operários, imigrantes e sertanejos. Os jogadores, torcedores e sócios das agremiações populares não escapavam a esse tipo de desqualificação.

Conforme foi o futebol se espraiando pela cidade do Rio de Janeiro, cresceram os conflitos simbólicos ao seu redor. Os clubes mais populares colocavam em xeque tanto as intencionalidades quanto os privilégios das agremiações das elites. Tendo em vista esse novo quadro, procurou-se estabelecer restriçóes a sua plena participação.

Uma das iniciativas entabuladas foi a tentativa de instituição de novos regulamentos, o que sempre foi encarado com críticas, não logrando os resultados a princípio esperados. Para além disso, o mais comum mesmo foi a propagação de certas representações na imprensa: os jornais foram agências centrais na construção de estigmas sobre as agremiações do subúrbio.

Tais clubes não ficaram inertes frente a esse processo. Não só houve contestações veiculadas na própria grande imprensa, denunciando-se mesmo o trato injusto e desigual, como por vezes contou-se com o apoio dos jornais de bairro, que não tinham o mesmo poder de repercussão, mas gozavam de certa influência local.

Para alguns desses periódicos, defender um clube local não era apenas uma postura ligada à prática do futebol, mas sim parte da pugna pelos interesses da região. Por isso, distintamente da grande imprensa, denunciavam as supostas arbitrariedades e injustiças contra as agremiações da zona suburbana. Vejamos, por exemplo, a matéria publicada no Bangú-Jornal, na seção Vida Sportiva, em 14 de julho de 1918. 
O cronista comentava, com indignação, a interdição do campo do Bangu, decisão tomada pela Liga Metropolitana em função da violência constantemente observável nos jogos do clube. Para o jornalista, tratava-se de uma "injusta medida", que causava enormes prejuízos materiais ao "nosso valoroso club" 36 . A propósito, nas atas das reuniōes da diretoria, podemos perceber que já vinha se denunciando uma certa perseguição por parte da entidade dirigentel.

Sabedor de todos esses fatos, celebrava o cronista: "as responsabilidades da Liga já se acham bem apuradas no judiciário e em breve será proposta uma acção contra a mesma pedindo uma forte indenização por perdas e dannos" ${ }^{36}$. Para ele, essa iniciativa seria "uma boa e bastante aproveitável licção para os despeitos da Liga e uma estupenda victoria moral para o nosso querido club". Tal posicionamento era encarado como uma forma de a zona suburbana fazer-se respeitar.

$\mathrm{Na}$ mesma semana, a partir do que informara o periódico suburbano, dois grandes jornais de grande circulação se posicionaram. O Correio da Manhã considerou a ameaça do Bangu como uma "petulante ousadia de perturbar a doce paz dos nossos amigos da liga Metropolitana" ${ }^{37}$. Já A Época interpelou a diretoria do clube, informando que:

o representante do Bangú desmentiu categoricamente que seu club pretendesse chamar a juízo a L.M.D.T. ${ }^{\mathrm{m}}$, para ser indenizado pelas perdas a dannos decorrentes da interdição do campo da mesma sociedade. Ainda bem... ${ }^{38}$.

$\mathrm{O}$ cronista do Bangú-Jornal não deixa passar em branco a postura de $A$ Época: "os leitores bem conhecem o valor significativo das 'reticências' que sempre envolvem dúvida, ironia, malicia... etc" 39 . Mais ainda, procurou esclarecer que o noticiado não se tratara de uma informação equivocada:

a) Pelos processos regulares e perante autoridades competentes, depuseram pessoas qualificadas para se apurar as responsabilidades do referee que presidiu o jogo e que apresentou á Liga o relatório que deu causa á interdição do campo. b) Chamado o referee á depor, defendeu-se, negando o facto principal: Logo... atirou "com as responsabilidades" para a Liga rendendo uma sincera homenagem já verdade, o nosso illustre contradictor será capaz de negar, ou por outra, de desmentir o exposto? Não cremos, mas si for, falaremos mais claro ainda... 39 .

$\mathrm{O}$ que parece ter realmente irritado foi o desmentido e a atuação tímida da diretoria do Bangu. Para ele, o bairro não poderá se orgulhar se o clube: n'um gesto digno e nobre e tendo um presidente honrado (todo feito de paz e amor) sujeitar-se a todos os prejuízos sofridos, conformando-se apenas com a desaffronta que sua altiva directoria conseguiu em processo regular, e desistindo de chamar a Liga às contas.

O periódico local defendia, mas também cobrava: recuar não dignificava os "valorosos rapazes do club". Dessa forma, segundo seu olhar, permitir-se-ia que a Liga seguisse utilizando artifícios para neutralizar os clubes do subúrbio, de forma que "suas injustiças (tomara que não se reproduzam - é sempre melhor) consigam as mesmas condescendências..." 39 .

$\mathrm{O}$ assunto merece ser mais investigado. Temas como, por exemplo, as ligas que pelo subúrbio foram organizadas permanecem sendo pouco discutidos ${ }^{\mathrm{n}}$. Como recomendação para outros estudos, apontamos a necessidade de manusear mais cuidadosamente fontes que expressem por outro ângulo os pontos de vista dos sócios e torcedores das agremiações do subúrbio. Jornais locais e atas das reuniōes, por exemplo, ajudariam a melhor entender uma espécie de resolução por regras próprias de comportamento, nos revelando importantes pistas sobre as estratégias cotidianas daqueles atores.

Esse tipo de abordagem poderia certamente contribuir para tornar mais múltiplos e diversos nossos estudos e nossa compreensão sobre o processo de consolidação do futebol brasileiro, que não foi somente uma obra das elites, mas sim um constructo em que também as periferias participaram ativamente.

\section{Notas}

a. Alguns exemplos de novos clubes que se espalharam pela cidade: Bangu Athletic Club (1904), Sport Club Mangueira (1906), Brasil Athletic Club (1906), Cascadura F.C. (1906), Club Atlético Méier (1906), Esperança Athletic Club (1907). Andarahy Athletico Club (1909).

b. Consideramos como membros das elites aqueles que detinham o poder econômico, político e cultural. Eram constituídas tanto pelos proprietários dos meios de produção quanto pelo que pode ser chamado de setores médios ou pequena burguesia. Inicialmente, eram os nobres, políticos e aristocratas ligados à economia agroexportadora. Posteriormente 
também as integraram certos grupos urbanos, como militares de alta patente, envolvidos com o alto comércio e indústria, bem como parte da intelectualidade.

c. Adotamos o conceito de representação sugerido por Roger CHARTIER $^{40}$, isso é, a forma como se constrói visões sobre fatos sociais, de forma distinta no seio de um mesmo ou diferente tempo e espaço. Por meio das representações, concede-se sentido e significado, concretude à vida cotidiana.

d. Fundada em 8 de julho de 1905, por representantes do América Foot-Ball Club, do Bangu Athletic Club, do Botafogo F.C., do Fluminense F.C. e do Foot-Ball and Athletic Club, inicialmente denominada Liga Metropolitana de Football, foi a pioneira entidade organizativa do futebol no Rio de Janeiro, promovendo os primeiros campeonatos. Depois surgiram outras ligas, mas a Metropolitana manteve-se sempre como a de maior prestígio.

e. O Correio da Manhã circulou até 1974. Um dos motivos do encerramento de suas atividades, por razões financeiras, foi a perseguição política do governo de exceção, por sua posição contrária à ditadura.

f. Noel de Carvalho foi presidente do Bangu de 1915 a 1917.

g. Andrew Procter foi um dos fundadores do Bangu Athletic Club, ocupando cargos de secretário, tesoureiro e presidente do clube nos anos de 1909 a 1910.

h. Nico Miranda foi um dos fundadores do Andarahy, além de cronista dos jornais O Paiz e A Época.

i. Esse clube, em 1914, foi renomeado para Paysandu Athletic Club.

j. Por exemplo, um tumulto em uma partida realizada entre o America e o Botafogo, em 1914, foi apresentado como mero fruto do amor dedicado ao clube ${ }^{7}$.

k. Para mais informações sobre as posições de Lima Barreto no que se refere ao futebol, ver AUGUSTO ${ }^{41}$ e CAPRARO ${ }^{42}$.

1. Acta da Sessão da Diretoria do Bangu Athletic Club de 24 de abril de 1918, 15 de maio de 1918, 22 de maio de 1918, 12 de junho de 1918.

m. A essa altura o entidade já era denominada Liga Metropolitana de Desportos Terrestres.

n. Para mais informações, ver MaLAiA ${ }^{8}$.

\begin{abstract}
Violent and disorderly: representations of two suburb clubs in Rio de Janeiro press (decade of 10)

In order to better understand the process of consolidation of football in Rio de Janeiro, this article aimed to discuss the representations of two suburb clubs, Bangu and Andarahy, in Rio de Janeiro press in the 10s. The time frame adopted considered that it was a period in wich there was an increase in the number of conflicts on the stadiums and attempts to restrict the participation of certain groups in the initiatives of the Liga Metropolitana de Sports Athleticos. To reach the objective, we analyzed major newspapers, especially the Correio da Manhã and 0 Imparcial. Finally, we concluded that there was a process of stigmatization of these associations investigated, which did not prevent them to participate actively in the dissemination of the football.
\end{abstract}

KEY WORDS: History; Football; Sport; Rio de Janeiro.

\title{
Referências
}

1. Da Matta R. O que faz o brasil, Brasil? Rio de Janeiro: Rocco; 1986.

2. Leite Lopes JS. Classe, etnicidade e cor na formação do futebol brasileiro. In: Batalha CHM, Da Silva FT, Fortes A, organizadores. Cultura de classe. Campinas: UNICAMP; 2004. p. 121-66.

3. Guedes SL. Futebol brasileiro: instituição zero [dissertação]. Rio de Janeiro (RJ): UFRJ; 1977.

4. Hardman FF. Nem pátria, nem patrão: vida operária e cultura anarquista no Brasil. São Paulo: Brasiliense; 1983.

5. Decca, MAG. A vida fora das fábricas: cotidiano operário em São Paulo (1920-1934). Rio de Janeiro: Paz e Terra; 1987.

6. Antunes FMRF. Futebol de fábrica em São Paulo [dissertação]. São Paulo (SP): Universidade de São Paulo; 1992.

7. Pereira LAM. Footballmania: uma história social no futebol do Rio de Janeiro: 1902-1938. Rio de Janeiro: Nova Fronteira; 2000. 
8. Malaia JM. Revolução vascaína: a profissionalização do futebol e inserção sócio-econômica de negros e portugueses na cidade do Rio de Janeiro (1915-1934) [tese]. São Paulo (SP): Universidade de São Paulo, Faculdade de Filosofia, Letras e Ciências Humanas; 2010.

9. Abreu AA, organizador. Dicionário histórico: biográfico brasileiro pós-1930. Rio de Janeiro: FGV; 2002.

10. Moraes, HS. Jogadas insólitas: amadorismo e processo de profissionalização no futebol carioca (1922-1924) [dissertação]. Rio de Janeiro (RJ): Universidade do Estado do Rio de Janeiro, Faculdade de Formação de Professores; 2009.

11. Gazeta de Notícias. 26 maio 1912; 6.

12. O Imparcial. 26 fev 1916; 9.

13. O Imparcial. 14 ago. 1913; 8.

14. O Imparcial. 29 jan. 1915; 8.

15. Jornal do Commercio. 15 mar. 1916; 8.

16. O Imparcial. 15 nov. 1915; 8.

17. Sports. 6 ago. 1915; 6.

18. Sports. 14 ago. 1915; 7.

19. O Imparcial. 3 fev. 1916; 7.

20. Gazeta de Notícias. 7 fev. 1916; 9.

21. O Imparcial. 8 fev. 1916; 9.

22. Correio da Manhã. 14 fev. 1916; 5.

23. O Imparcial. 15 fev. 1916; 9.

24. Correio da Manhã. 8 fev. 1916; 5.

25. O Imparcial. 26 nov. 1919; 10.

26. O Imparcial. 26 nov. 1919; 11.

27. Correio da Manhã. 23 out. 1916; 9.

28. O Imparcial. 11 jun. 1917; 8.

29. O Imparcial. 13 jun. 1917; 8.

30. Correio da Manhã. 4 maio 1922; 7.

31. Correio da Manhã. 5 maio 1922; 6.

32. Careta. 1 jan. 1921 ; 5.

33. Franco Júnior H. A dança dos deuses: futebol, sociedade, cultura. São Paulo: Companhia das Letras; 2007.

34. Correio da Manhã. 14 jul. 1919; 8.

35. Chalhoub S. Trabalho, lar e botequim: o cotidiano dos trabalhadores no Rio de Janeiro da Belle Époque. Campinas: UNICAMP; 2001.

36. Bangú-Jornal. 14 jul. 1918; 3.

37. Correio da Manhã. 17 jul. 1918; 6.

38. A Época. 18 jul. 1918; 9.

39. Bangú-Jornal. 21 jul. 1918; 3.

40. Chartier R. A história cultural: entre práticas e representações. Rio de Janeiro: Bertrand Brasil; 1990.

41. Augusto ECBS. Olho no lance: futebol e modernidade na crônica de Lima Barreto. XII Encontro Regional de História: usos do passado; 2006; Rio de Janeiro, BR. Rio de Janeiro: ANPUH/RJ; 2006. [citado 6 maio 2012]. Disponível em: http:// www.rj.anpuh.org/resources/rj/Anais/2006/conferencias/Emilia\%20Carolina\%20Bispo\%20dos\%20Santos\%20Augusto.pdf.

42. Capraro A. Futebol e sentimentalismo manifesto na crônica esportiva do início do século XX. I Encontro da ALESDE; 2006; Curitiba, BR. Curitiba: UFPR; 2008. [citado 6 maio 2012]. Disponível em: http://www.alesde.ufpr.br/ encontro/trabalhos/70.pdf.

\begin{tabular}{|c|c|}
\hline $\begin{array}{r}\text { ENDEREÇO } \\
\text { Nei Jorge Santos Junior } \\
\text { Universidade Federal do Rio de Janeiro } \\
\text { Instituto de Filosofia e Ciências Sociais } \\
\text { Programa de Pós-graduação em História Comparada } \\
\text { Largo de São Francisco, } 1 \text { - sala } 311 \\
\text { 200051-070 - Rio de Janeiro - RJ - BRASIL } \\
\text { e-mail: edfnei@hotmail.com }\end{array}$ & $\begin{array}{l}\text { Recebido para publicação: 12/05/2012 } \\
\text { Aceito: 30/04/2013 }\end{array}$ \\
\hline
\end{tabular}

422 • Rev Bras Educ Fís Esporte, (São Paulo) 2013 Jul-Set; 27(3):411-22 